The Canadian Mineralogist

Vol. 42, pp. 1563-1581 (2004)

\title{
PRESERVATION OF MICROBORINGS AS FLUID INCLUSIONS
}

\author{
Govert J.A. BUIJS ${ }^{\S}$, Robert H. GOLDSTEIN, Stephen T. HASIOTIS AND JenNifER A. ROBERTS \\ Department of Geology, 120 Lindley Hall, University of Kansas, \\ 1475 Jayhawk Boulevard, Lawrence, Kansas 66045, U.S.A.
}

\begin{abstract}
In this study, we identify endolithic microbial borings preserved as fluid inclusions in Pennsylvanian and Permian brachiopods from the subsurface of western Kansas. Endolithic microbial boring is a new biologically controlled mode of formation for inclusion vacuoles. The microborings are preserved as three types of linear, curved, and branched arrays of tubular fluid inclusions, each with a distinct diameter. Each of the thousands of microborings observed in 60 brachiopod fragments has changed shape by forming calcite partitions that have divided the original tubules into separate aligned fluid inclusions. On average, only $35 \%$ of the original lengths of the microborings are preserved as fluid inclusions; values range from less than 5\% to about $85 \%$. Enlarged diameters of inclusions, variable vapor-to-liquid ratio in paired inclusions, and low salinities of inclusions indicate that closed-system necking down is one of the mechanisms responsible for alteration of the microborings. Preservation of parallel walls, fillings with luminescent calcite and high salinity of included fluid indicate that open-system cementation is the other mechanism responsible for alteration of the microborings. As most inclusions have leaked and refilled or stretched during thermal re-equilibration, these fluid inclusions are not particularly reliable as records of diagenetic history. The linear arrays of fluid inclusions that remain after alteration of the original microboring are excellent as trace fossils of microbial activity. The record preserved here indicates how fluid-inclusion techniques can be applied to identify and determine the timing of entrapment of microbial trace fossils in ancient Earth and extraterrestrial materials.
\end{abstract}

Keywords: fluid inclusions, microbes, borings, trace fossils, ichnology, endoliths, origin of life, extraterrestrial life, life on Mars.

\section{SOMMAIRE}

Dans ce travail, nous identifions des forages endolithiques effectués par des microbes, préservés sous forme d'inclusions fluides dans des brachiopodes d'âge pennsylvanien ou permien provenant des roches enfouies de l'ouest de l'état du Kansas. De tels forages endolithiques microbiens constituent un nouveau mode de formation régi biologiquement d'inclusions vacuolaires. Les microforages sont conservés en agencements linéaires, courbes or branchés d'inclusions fluides tubulaires, chacun avec un diamètre distinct. Chacun des milliers de tels microforages observés dans 60 fragments de brachiopode a changé de morphologie suite à la formation de cloisons de calcite qui divisent le microtube en inclusions fluides alignées. En moyenne, seulement 35\% des longueurs originelles des microforages ont été conservées sous forme d'inclusions fluides; les valeurs en fait varient de moins de 5\% à environ $85 \%$. Les diamètres élargis des inclusions, un rapport variable de phases vapeur à liquide, et une faible salinité de la phase en occlusion indique qu'une atténuation du microforage en système fermé est en partie responsable de l'altération des microforages. La préservation de parois parallèles, un remplissage avec la calcite luminescente, et une phase fluide incluse à salinité élevée indiquent plutôt une cimentation en système ouvert comme mécanisme d'altération. Parce que la plupart des inclusions ont subi des fuites et ont été remplies de nouveau ou étirées lors d'un ré-équilibrage thermique, ces inclusions ne sont pas des indicateurs tout-à-fait fiables de l'évolution diagénétique. Les agencements linéaires d'inclusions qui restent après l'altération des microforages originels fournissent d'excellents indicateurs fossiles d'une activité microbienne. Les vestiges décrits ici montrent comment les techniques d'étude des inclusions fluides peuvent fournir une identification et une détermination de la relation de temps de piégeage de ces traceurs microbiens fossiles dans les matériaux anciens terrestres ou extraterrestres.

(Traduit par la Rédaction)

Mots-clés: inclusions fluides, microbes, forages, fossiles traces, ichnologie, endolithes, origine de la vie, vie extraterrestre, vie martienne.

$\S \quad$ E-mail address: gbuijs@ku.edu 


\section{INTRODUCTION}

Calcitic skeletal fragments in Pennsylvanian and Permian limestones from western Kansas contain abundant tubular fluid inclusions that are distributed in alignment, following linear, curvilinear, and branching paths through the fragments. These so-called "linear arrays of tubular fluid inclusions" are interpreted to have formed as microborings, made by such endolithic micro-organisms as cyanobacteria, green and red algae, and fungi. Microborings in calcite are common in deposits of modern marine and freshwater environments (e.g., Golubic et al. 1975). They have been found in sedimentary rocks as old as early Proterozoic (Golubic \& Seong-Joo 1999). The shape of the microboring is controlled by the organism, and morphologies are known by analogy to modern systems (Figs. 1a, b, c; see examples in Golubic et al. 1975, Budd \& Perkins 1980, Vogel et al. 2000). Microborings are less than $100 \mu \mathrm{m}$ in diameter and can form complicated networks of hollow tubes that may penetrate several millimeters into minerals (Vogel et al. 2000, Perry \& Macdonald 2002). Endolithic microorganisms make microborings by initiating directed dissolution of the mineral (Vogel et al. 2000, Ehrlich 2002).
An endolithic lifestyle may shield a micro-organism from environmental stresses such as competition, predation, currents, intense radiation, or desiccation (Atlas \& Bartha 1998, Golubic \& Seong-Joo 1999). Boring into the substrate may also provide valuable nutrients for the micro-organism (Atlas \& Bartha 1998).

Microborings can be sealed by cementation, and preserved as fluid inclusions. Sealed microborings are a new class of fluid inclusion because of their biological origin, in which the timing of formation of the inclusion vacuole is well constrained to the realm in which endolithic micro-organisms lived. As original morphologies of microborings are known, changes in shape, volume, and fluid content can be used as evidence for the rates, styles, and mechanisms of modification of fluid inclusions in calcite.

Fluid inclusions formed by micro-endolithic borers are trace fossils of ancient micro-organisms. They represent a newly described mode of trace-fossil preservation that is likely common in deposits of many carbonate systems (e.g., Golubic et al. 1975). In this detailed study of approximately 300 million-year-old trace fossils, we document the extent to which the original shape of the microborings can change through time. We propose cri-
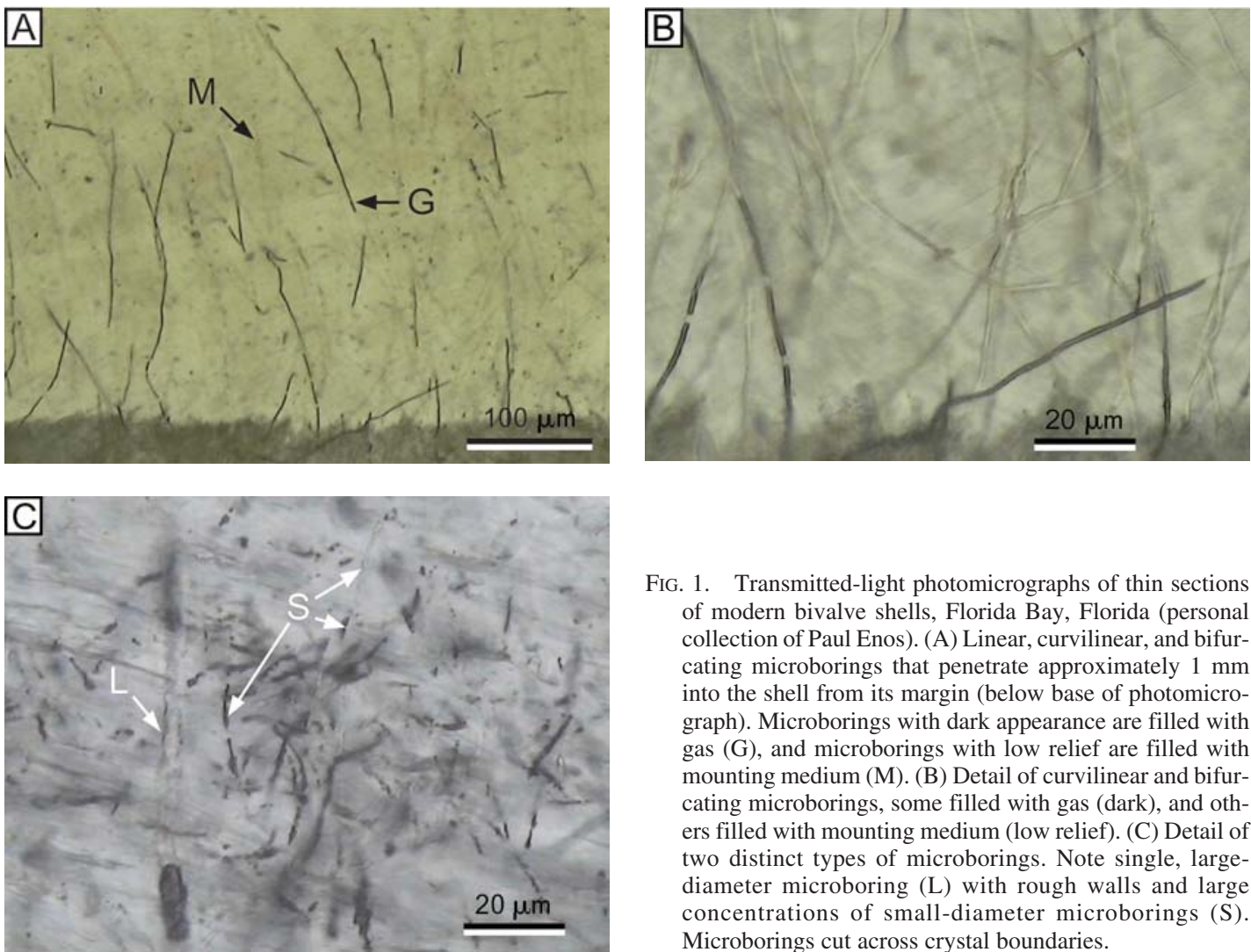

FIG. 1. Transmitted-light photomicrographs of thin sections of modern bivalve shells, Florida Bay, Florida (personal collection of Paul Enos). (A) Linear, curvilinear, and bifurcating microborings that penetrate approximately $1 \mathrm{~mm}$ into the shell from its margin (below base of photomicrograph). Microborings with dark appearance are filled with gas $(\mathrm{G})$, and microborings with low relief are filled with mounting medium (M). (B) Detail of curvilinear and bifurcating microborings, some filled with gas (dark), and others filled with mounting medium (low relief). (C) Detail of two distinct types of microborings. Note single, largediameter microboring (L) with rough walls and large concentrations of small-diameter microborings (S). Microborings cut across crystal boundaries. 
teria by which microbial traces can be identified in the most ancient samples, even after changes in shape have occurred. Such basic observations are essential in reconstructing paleoecology and interpreting the rock record of the origin of life on Earth. Understanding the morphology and diversity of microendolithic trace fossils represents one of the best opportunities for discovering ichnofossil evidence of life in extraterrestrial rocks and meteorites (Hasiotis et al. 2002). Also, our study will be useful in distinguishing between extraterrestrial microendolithic borings and contamination of extraterrestrial material that has been exposed to Earth's biosphere.

\section{APPROACH}

This study is based on microscopic examinations of samples from two cores taken from the subsurface of western Kansas (Fig. 2). All samples studied were not heated during sample preparation. Fossiliferous marine carbonate rocks, mostly of Pennsylvanian age, were sampled from the Rebecca Bounds core, Greeley County, western Kansas. Additional samples evaluated are early Permian in age and taken from the nearby Shankle core, Kearney County, western Kansas.

The Pennsylvanian-Permian samples from the Rebecca Bounds core span core depths from 1060 to 1570 meters. Permian samples from the Shankle core span core depths from 907 to 937 meters. Most of the carbonates in these intervals were deposited in a shallow tropical sea and have a diverse marine biota consisting of crinoids, bryozoans, brachiopods, bivalves, gastropods, corals, phylloid algae, borings and micritic rims and envelopes. Pre-compaction diagenesis led to deposition of marine cements and minor meteoric

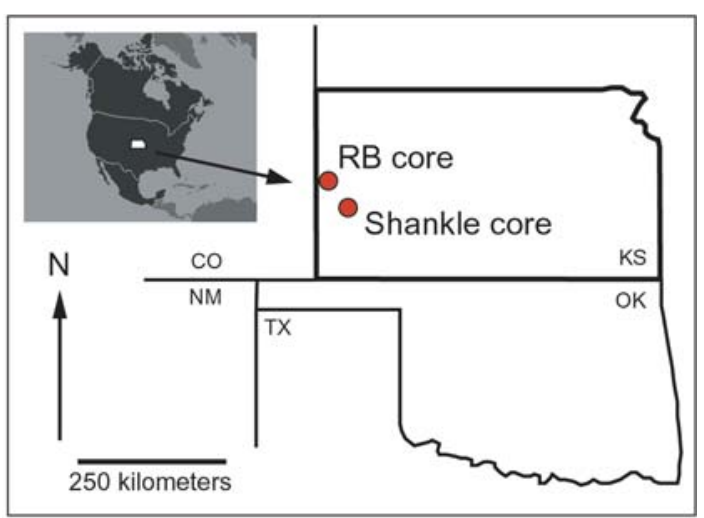

FIG. 2. Diagram showing the location of the Rebecca Bounds core (RB core) from Greeley County and Shankle 2-9 core from Kearny County in western Kansas. Both cores are kept at the repository at the Kansas Geological Survey. cement associated with cyclothem-capping events of subaerial exposure (Buijs \& Goldstein 2001). Post-compaction cementation is dominated by dolomite and calcite precipitated by the reflux of brines associated with Permian evaporite deposition (Goldstein et al. 1991, Luczaj \& Goldstein 2000, Buijs \& Goldstein 2001). Later, warm fluids migrating through these rocks generated temperatures of homogenization of up to about $140^{\circ} \mathrm{C}$ (Buijs \& Goldstein 2003).

In total, 60 brachiopod fragments containing thousands of linear arrays of tubular fluid inclusions were observed using transmitted-light petrography. Fifty-two linear arrays of fluid inclusions were measured to quantify the variability in length, diameter, and distribution of fluid inclusions (Table 1). Total original lengths of linear arrays were measured only for borings that did not appear to have been truncated along the top or base of the thin sections. The measurements consist of the length of all inclusions along each array of aligned fluid inclusions, as well as the length of the space separating the inclusions and the distance from the last inclusion of an array to the shell surface. Lengths are expressed in two ways, one in which the length is measured

TABLE 1. DESCRIPTIVE STATISTICS FOR FIFTY-TWO MEASURED ARRAYS OF FIUID INCLLUSIONS GROLPED BY TYPE OF ARRAY

\begin{tabular}{|c|c|c|c|c|c|c|}
\hline $\begin{array}{l}\text { Diam- } \\
\text { eter }\end{array}$ & $\begin{array}{l}\text { Length } \\
\text { wall to } \\
\text { distal } \\
\text { inclu- } \\
\text { sion } \\
\text { jim }\end{array}$ & $\begin{array}{l}\text { Surn } \\
\text { |entghth } \\
\text { al| } \\
\text { inclu- } \\
\text { Sions } \\
\text { flrm }\end{array}$ & $\begin{array}{c}\begin{array}{c}\text { Sum } \\
\text { length } \\
\text { partition }\end{array} \\
\mu \mathrm{mm}\end{array}$ & $\begin{array}{l}\text { Length } \\
\text { proximal } \\
\text { to fistal } \\
\text { inclu- } \\
\text { sion } \\
\text { j!n }\end{array}$ & $\begin{array}{l}\text { Length } \\
\text { wall to } \\
\text { proximal } \\
\text { inclit- } \\
\text { sion } \\
\text { pmm }\end{array}$ & $\begin{array}{l}\text { Presenved } \\
\text { length } \\
\text { wall pros } \\
\text { to distal } \\
\text { inclusion } \\
\%\end{array}$ \\
\hline
\end{tabular}

Alt

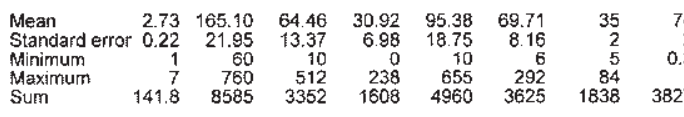

Type 1 ( $\mathrm{n}=31$ )

$\begin{array}{lrrrrrrrr}\text { Mean } & 1.65 & 177.23 & 69.65 & 30.52 & 100.16 & 77.06 & 36 & 73 \\ \text { Standard error } & 0.08 & 28.96 & 18.64 & 8.02 & 23.77 & 12.95 & 3 & 3 \\ \text { Minimum } & 1 & 60 & 10 & 0 & 10 & 6 & 5 & 35 \\ \text { Maximum } & 2 & 620 & 512 & 177 & 594 & 292 & 84 & 100 \\ \text { Sum } & 51 & 5494 & 2159 & 946 & 3105 & 2389 & 1104 & 2270\end{array}$

Type $2(n=15)$

$\begin{array}{lrrrrrrrr}\text { Mean } & 3.59 & 160.40 & 65.00 & 39.20 & 104.20 & 56.20 & 36 & 71 \\ \text { Standard error } & 0.17 & 47.33 & 26.25 & 17.58 & 43.00 & 8.51 & 4 & 5 \\ \text { Minimum } & 2.4 & 74 & 10 & 0 & 10 & 8 & 10 & 30 \\ \text { Maximum } & 4 & 760 & 417 & 238 & 655 & 105 & 59 & 100 \\ \text { Sum } & 53.8 & 2406 & 975 & 588 & 1563 & 843 & 542 & 1071\end{array}$

Type $3(\mathrm{n}=6)$ \begin{tabular}{lrrrrrrrr} 
Mean & 6.17 & 114.17 & 36.33 & 12.33 & 48.67 & 65.50 & 32 & 81 \\
Standard errer & 0.17 & 14.52 & 5.52 & 6.25 & 10.68 & 5.34 & 3 & 7 \\
Minimum & 6 & 80 & 22 & 0 & 24 & 46 & 24 & 57 \\
Maximum & 7 & 175 & 54 & 40 & 92 & 83 & 45 & 100 \\
\hline
\end{tabular}

Sum

Cofumns show measurements of clameter, the distance between the shell wall anc the most interior inclusion of a single artay (measurement that is the best approximation of the original length of the microboning), the sum of the length of all inclusions (a measure of the amounh of microboring that is mot cemented closedy
the sum of the length of calcite partitions separating the inclusions along an array the sum of the length of calcite partitions separating the inclusions along an array (measture of amolint of microboring that has closed,. length proximal to distal
inclusion (the distance along an array of inclusions betweent the inclusion closest to the shell wall and the inclusion most distal from the shell wali), (ength of wall to pioximal inclusion (distance between the shell wall and the closest inclusion in an array), preserved length wall to distal inclusion (an approximate measure of percent preservation of the eriginal boring), and preserved length of proximal to distal inclusions). 


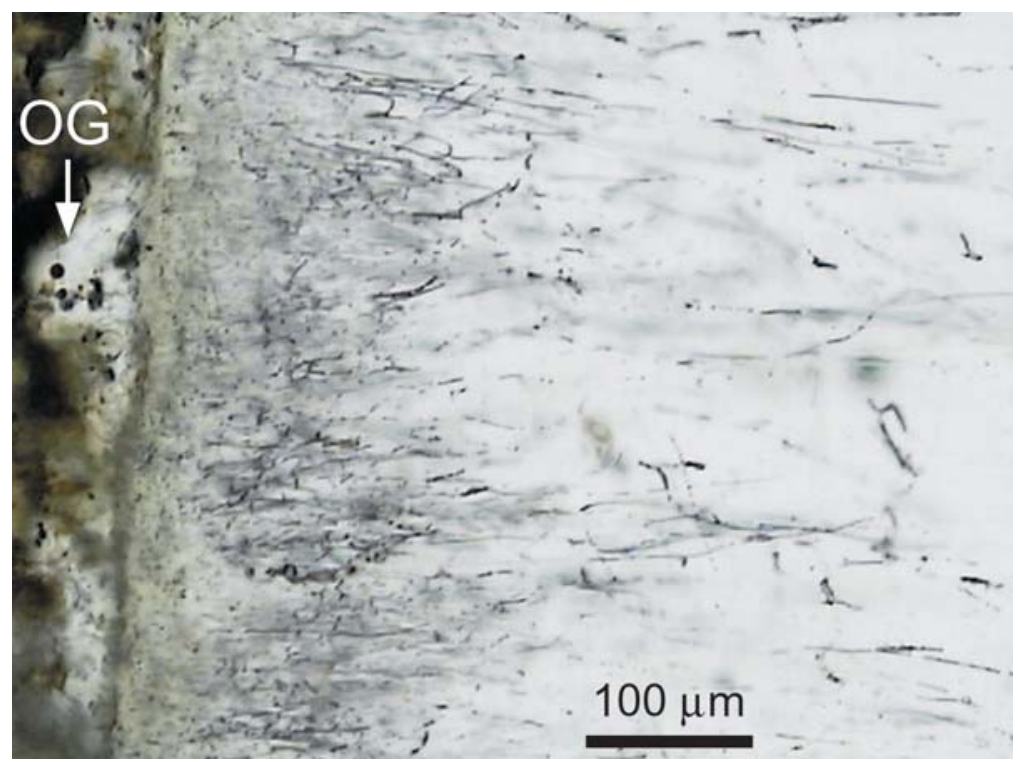

FIG. 3. Transmitted-light, thick-section photomicrograph of linear arrays of fluid inclusions in a brachiopod shell. The arrays show up as dark thin lines in the clear prismatic layer of the shell and are aligned perpendicular to the shell surface (left) from which they appear to originate. The darker brownish area on the left side is lime mudstone matrix and micritic rim. The shell contains a small irregular calcite overgrowth (OG) that shows up as clear areas between the matrix and the micritic rim of the shell.

between the shell wall and the inclusion most distal from the wall (wall-to-distal inclusion length), and the other in which the length is measured between the most proximal and the most distal inclusion (proximal-to-distal inclusion length). Each should be regarded as a minimum length.

All samples were prepared using cold-preparation techniques aimed at preventing thermal re-equilibration of the fluid inclusions (Goldstein \& Reynolds 1994). After petrographic analysis of fluid inclusions, microthermometry of the fluid inclusions was done on a Linkam heating and freezing stage fitted with a $100 \times$ objective. All heating work was done before freezing work, to avoid alteration of fluid inclusions before homogenization runs. Cathodoluminescence petrography was conducted after all fluid-inclusion work was complete.

\section{Origin of Linear ARrays of InCLUSIONS}

\section{Petrographic data}

Linear arrays of tubular fluid inclusions (Fig. 3) were found in 23 samples of limestone of the PennsylvanianPermian interval. The tubular fluid inclusions occur in brachiopod shells, likely from the orders Spiriferida or
Terebratulida, and in skeletal grains interpreted as brachiopod fragments. The tubular structures are not punctae, and they are not related to punctae in the brachiopod shells. They do not occur in calcite cement overgrowing the brachiopod fragments. Lithologies containing the brachiopods include fossiliferous wackestone, fossiliferous grainstone, and coated grain packstone and grainstone.

The best-preserved and most abundant tubular fluid inclusions are located in the inner prismatic layer of the brachiopod shells. Outer fibrous layers contain only poorly preserved or less abundant fluid inclusions. Most commonly, the linear arrays of inclusions are aligned perpendicular to the shell's surface from which they appear to originate, and penetrate toward the shell's interior (Fig. 3). They propagate inward from the exterior and interior surfaces of the shells as well as from some broken margins of shell fragments.

Cross sections of the tubular inclusions in the brachiopods are circular or ovoid. Individual inclusions are aligned in a curvilinear, straight, or branched manner, forming a linear array. The inclusions give an initial and incorrect impression that they were trapped along healed fracture surfaces. In three dimensions, however, it is clear that the inclusions are tubular and arranged linearly, as opposed to being arranged on two-dimensional 


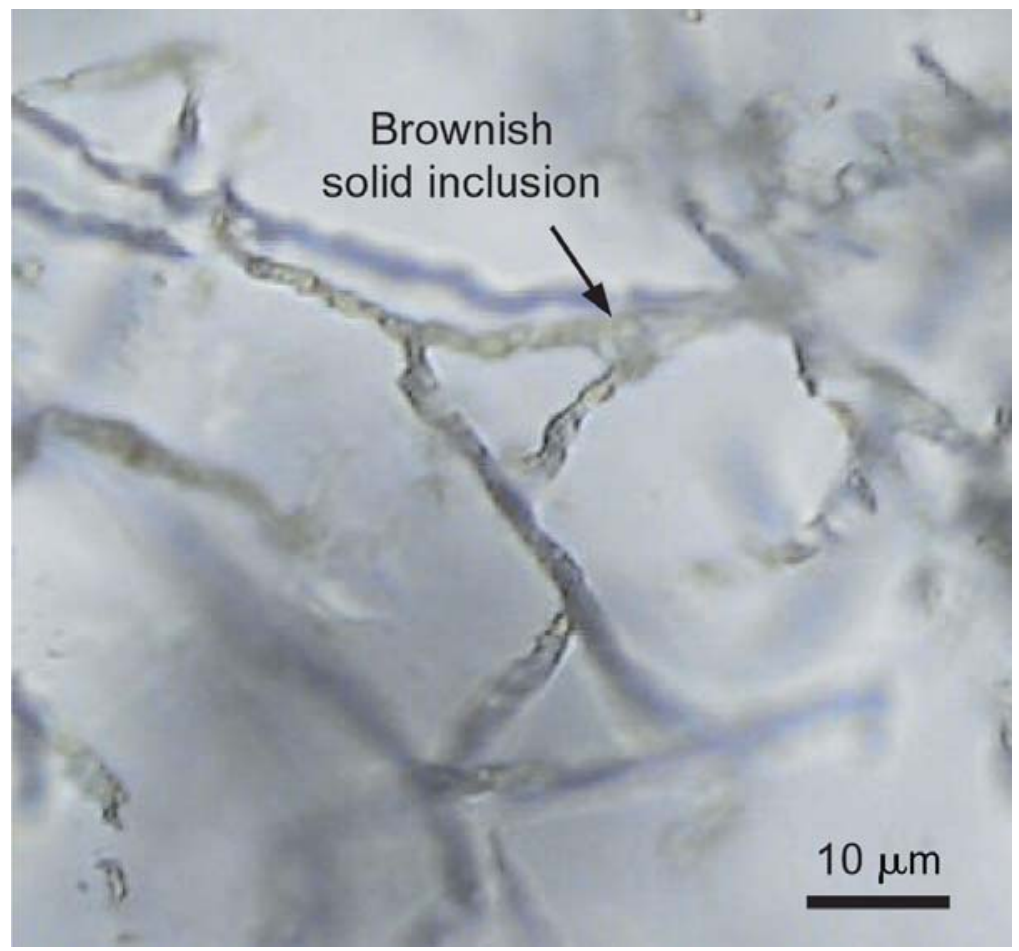

FIG. 4. Transmitted-light, thick-section photomicrograph of network of relatively wellpreserved tubular fluid inclusions. The walls of the tubes are rough, and the diameters of the tubes vary commonly by less than one micrometer. Some tubes contain brownish solid inclusions, assumed to be organic matter.

surfaces. They result from sealing fluid within tubular vacuoles.

The spacing of linear arrays of tubular inclusions varies within and among fragments. Dense clusters are most common near the margin of shells, achieving densities of 50 to 60 linear arrays per $100 \mu \mathrm{m}$ of linear distance along the shell margin, within the entire thickness of a $50 \mu \mathrm{m}$ thin section. Other areas yield only a few linear arrays per $100 \mu \mathrm{m}$ of linear distance along the shell margin.

The traceable length of the linear arrays is commonly between 80 to $120 \mu \mathrm{m}$, and the longest array reaches $1.6 \mathrm{~mm}$. The variation in inclusion diameter is typically small within each array of inclusions, varying normally by no more than $1 \mu \mathrm{m}$ (Fig. 4). Among the measured arrays, there are distinct differences in morphology and diameter (Table 1), which form the basis of a three-part classification (Fig. 5). These three different groups commonly occur together in the same brachiopod fragment, but without clear cross-cutting relationships.

The first and most common group (type 1) consists of linear arrays of inclusions with a diameter between 1 and $2 \mu \mathrm{m}$. The linear arrays are long (80 to $620 \mu \mathrm{m}$; average of $244 \mu \mathrm{m}$ ), and relatively straight to curved (Fig. 6). The linear arrays of inclusions are more or less evenly distributed along the shell surface, but dense clusters also are common. Some of the linear arrays of inclusions have a kink or strong curve. About $5 \%$ of the linear arrays bifurcate toward the interior of the shell (Fig. 7). Most of the linear arrays are perpendicular to the shell surface along the margin of the shell, and some curve in the shell interior to parallel the shell surface.

The second group of linear arrays (type 2) is very similar to the first group in morphology and distribution, but the diameter of the inclusions is larger, varying between 2.4 and $4 \mu \mathrm{m}$ (Fig. 7). The average measured length is $200 \mu \mathrm{m}$, with a range of 78 to $760 \mu \mathrm{m}$

The third group (type 3 ) consists of linear arrays of inclusions that are wider ( 6 to $7 \mu \mathrm{m}$ diameter), straight and relatively short. The average length of an array is $114 \mu \mathrm{m}$, with a range between 80 and $175 \mu \mathrm{m}$ (Fig. 8). The linear arrays of inclusions are more or less evenly distributed along the shell surface and are roughly perpendicular to it. Bifurcation toward the shell interior is present, but rare compared to type 1 and type 2 . 

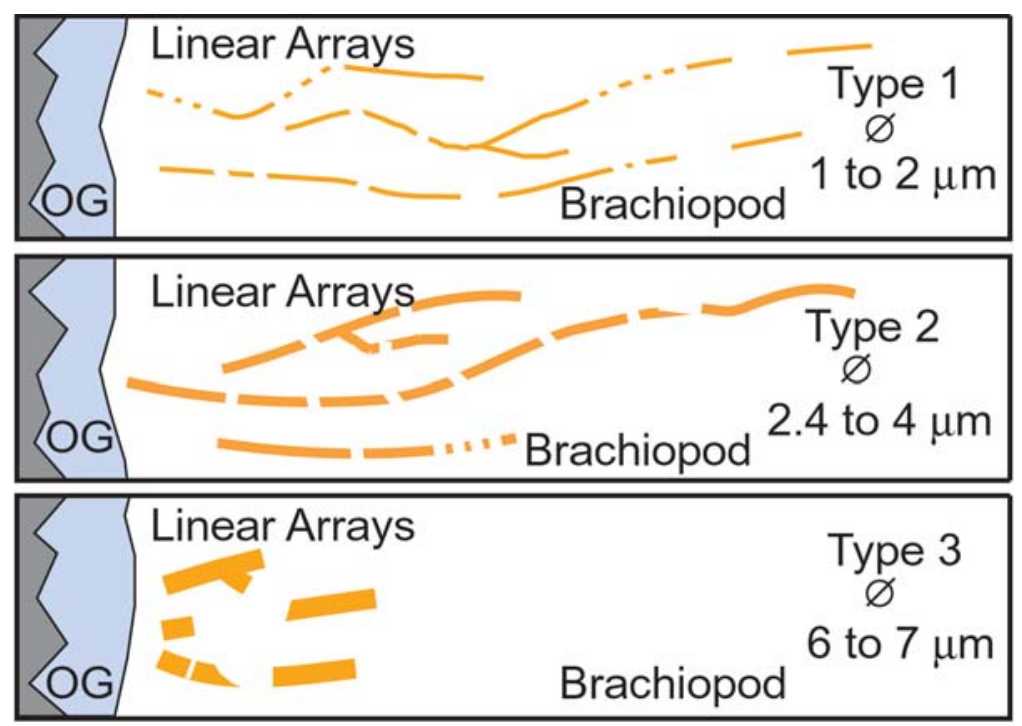

FIG. 5. Schematic diagram of the general morphology of the three different types of linear arrays of fluid inclusions. The three-part classification is based on differences in diameter: type 1 is 1 to $2 \mu \mathrm{m}$, type 2 is 2.4 to $4 \mu \mathrm{m}$, and type 3 is 6 to $7 \mu \mathrm{m}$. The orange interrupted lines represent the arrays of fluid inclusions in the brachiopod shell (white area). The blue irregular area on the left is an early overgrowth of calcite (OG) on the exterior of the shell, and the gray area is lime mudstone matrix.

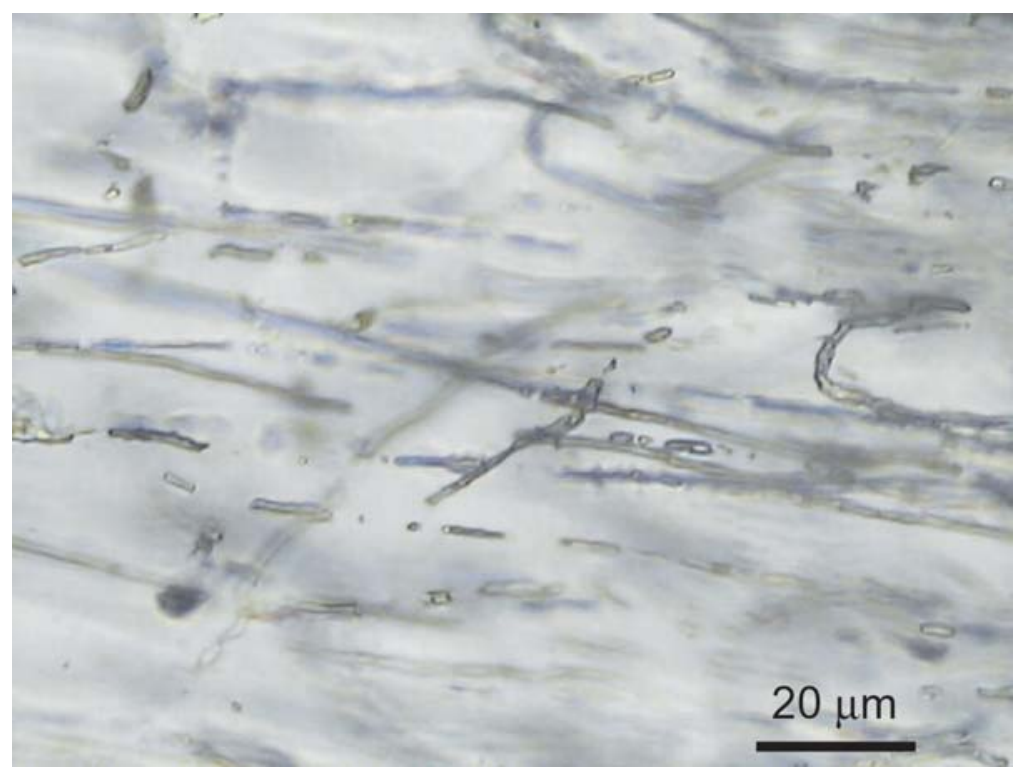

FIG. 6. Transmitted-light, thick-section photomicrograph of type-1 arrays of fluid inclusions. Typically, these arrays are long ( 80 to $620 \mu \mathrm{m}$; average of $244 \mu \mathrm{m}$ ), and relatively straight to curved, but kinks and strong curves also are common. Shell wall is to the right of the photograph (not shown). 


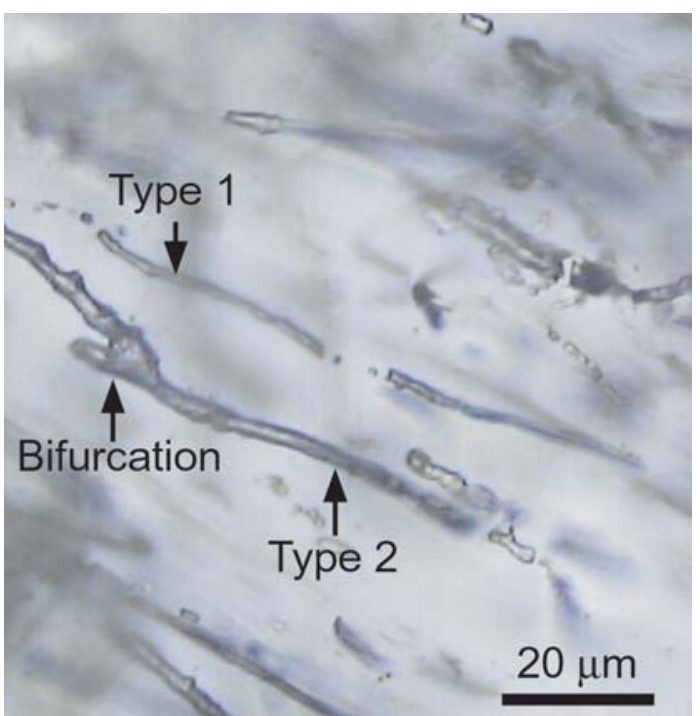

FIG. 7. Transmitted-light, thick-section photomicrograph illustrating bifurcation of type-2 tubular inclusion. Bifurcation occurs in about $5 \%$ of all the arrays and is commonly oriented toward the interior of the shell. Type-2 arrays are very similar to type-1 arrays in morphology and distribution, but the diameter of the inclusions is larger, varying between 2.4 and $4 \mu \mathrm{m}$. The average measured length is $200 \mu \mathrm{m}$, with a range of 78 to $760 \mu \mathrm{m}$. The diagram also shows type-1 arrays. Shell wall is to the right of the photograph (not shown).
The texture of the inner walls of the tubular inclusions varies depending on the size and fill of the inclusions. All those inclusions containing brownish solid material (organic matter?) appear to have rough walls (Fig. 4). Inclusions that are empty (leaked before or during preparation) or filled with aqueous liquid have either rough walls or smooth walls. Where the individual inclusions within a linear array are shorter, they tend to have smoother walls more commonly than the longer inclusions.

Of all the linear arrays observed, none appear to be continuous, i.e., without calcite partitions. All linear arrays show evidence of some interruption of the tube, resulting in a necked-down appearance, with original long cylinders broken into a series of shorter aligned inclusions. For the most part, the inclusions retain their cylindrical shape and have parallel walls. Within individual linear arrays of inclusions, the diameter among inclusions remains relatively consistent. Quantitative data on the distribution of calcite partitions within the aligned arrays are presented in a later section, and interpreted as the result of alteration of originally continuous tubular vacuoles.

With the exception of specimens that have been silicified, the brachiopods containing the linear arrays of inclusions appear to have preserved most of their original fibrous and prismatic shell texture without significant recrystallization (Fig. 9). In cathodoluminescence illumination, brachiopods are mostly nonluminescent,

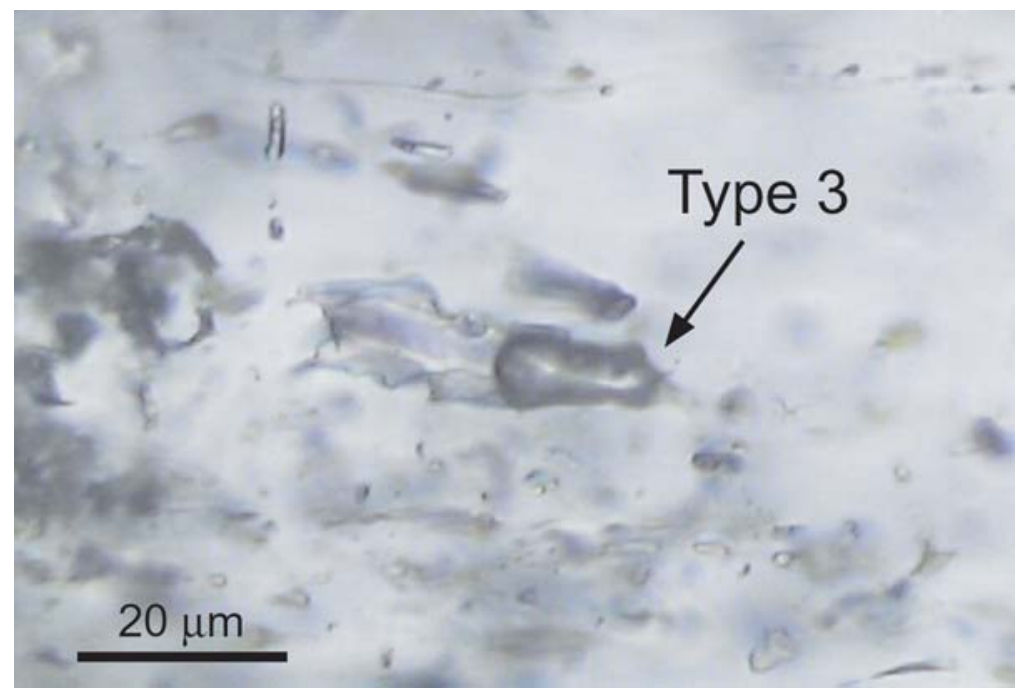

FIG. 8. Transmitted-light, thick-section photomicrograph of a type-3 array of fluid inclusions. This type of array consists of thick (6 to $7 \mu \mathrm{m}$ in diameter), straight and relatively short (average $113 \mu \mathrm{m}$, range between 80 and $175 \mu \mathrm{m}$ ) inclusions. The large inclusion at the tip of the arrow is gas-rich and very irregular in shape. Shell wall is to the right of the photomicrograph (not shown). 
with only minor patches of luminescent calcite cutting across the original brachiopod shell (Fig. 10). Matrix and calcite cement surrounding the brachiopods are commonly luminescent. The absence of luminescence in the brachiopods suggests that they are preserved without major amounts of recrystallization.

Brachiopods are at least partially encrusted in micritic rims (Fig. 11) or calcite cements that, in many cases, are syntaxial with the prisms of the brachiopod shells (Figs. 9, 10). Linear arrays of inclusions are absent in the overgrowth calcite. Presumably, the tubular vacuoles were already present in the brachiopods before the overgrowth precipitated. Inclusion fluids were then trapped in the brachiopods as calcite cement sealed the vacuoles.

\section{Interpretation}

We interpret the linear arrays of fluid inclusions in brachiopod shells as remnants of microborings, similar to the traces left by modern endolithic micro-organisms (Fig. 1), on the basis of morphology, size, and occurrence. The linear arrays seem to penetrate hard skeletal fragments from the surface inward, cutting across different shell layers and crystal boundaries. The gener- ally curved, straight, and branched morphology of the linear arrays of fluid inclusions and small diameters (1 to $7 \mu \mathrm{m}$ ) of the tubular inclusions are consistent with the size and shape of microborings observed in modern marine environments. In these environments, endolithic micro-organisms consist of photosynthetic cyanobacteria, green and red algae and chemo-organotrophic fungi (Golubic et al. 1975).

The size and shape of modern microborings are highly variable and may mimic the size of the boring organism. They also may reflect the organisms' behavior and response to such environmental stimuli as light penetration, abrasion, nutrient and oxygen availability, and predation (Budd \& Perkins 1980, Perry \& Macdonald 2002).

In this study, at least three distinct morphologies of microborings were observed, indicating an assemblage of three different types of endolithic microbes. These endoliths penetrated the brachiopod shell soon after the brachiopod died. This post-mortem infestation is inferred from penetration from both the interior and exterior surfaces and from broken margins of the brachiopod shells.

The microborings generally penetrate the brachiopod perpendicular to the shell surface. In modern envi-

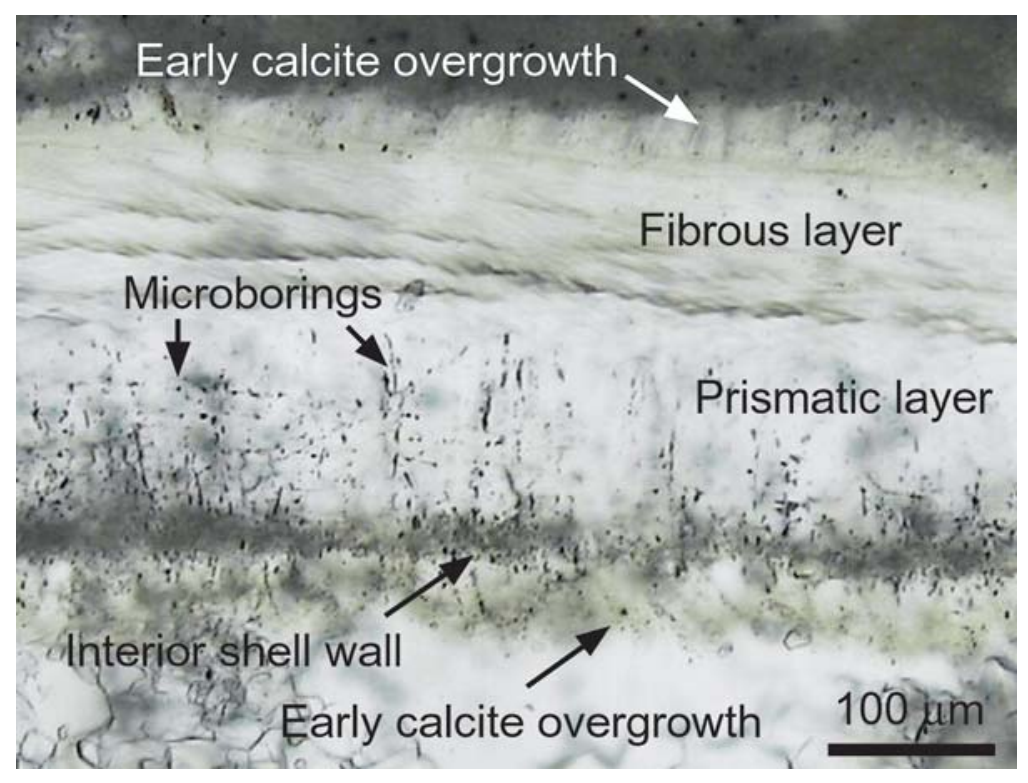

FIG. 9. Transmitted-light, thick-section photomicrograph showing the preserved original texture of a brachiopod shell. Brachiopods containing the linear arrays of tubular inclusions appear to have preserved most of their original fibrous and prismatic shell texture, without significant recrystallization. Notice that microborings are preserved as fluid inclusions that appear as thin black arrays penetrating the prismatic layer from below in this particular example. Notice that the prismatic layer was overgrown by calcite cement after the microborings had already formed. 

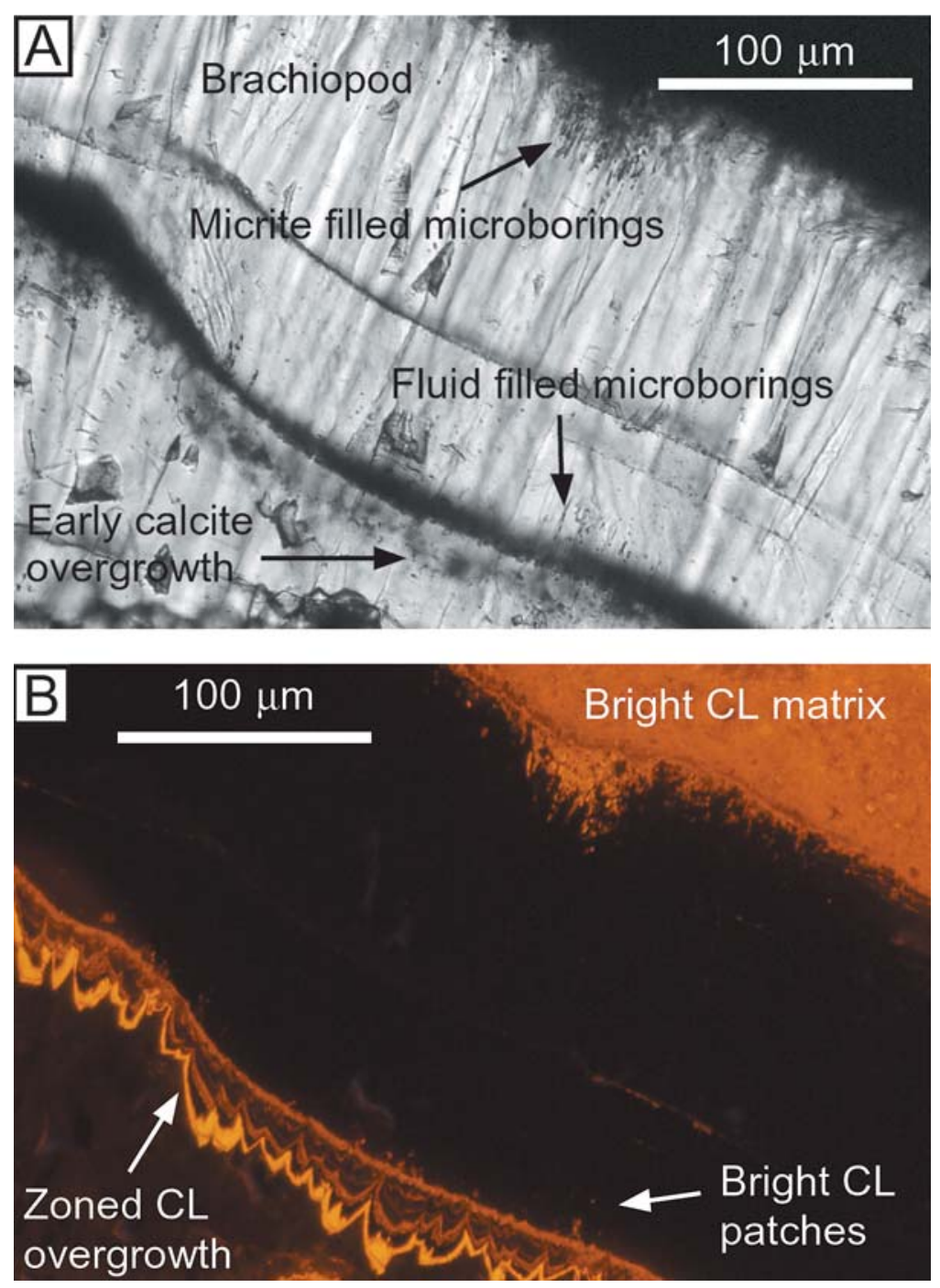

FIG. 10. (A) Transmitted-light, thick-section photomicrograph of brachiopod fragment with microborings. Notice the cluster of micrite-filled microborings along the top of the shell and fluid-filled microborings penetrating from the base of the shell. The dark area at the upper-right corner is lime mudstone matrix. The clear area at the lower-left is a pore filled with calcite cement. The base of the brachiopod fragment has a micritic rim covered by an early overgrowth of calcite cement. (B) Photomicrograph of the same field of view but with cathodoluminescence illumination. The brachiopod is generally non-luminescent (black), but the matrix and early overgrowth of calcite cement are luminescent. The micrite-filled microborings at the top of the shell show similar luminescence to the matrix. Areas near the fluid-filled microborings at the base of the shell show up as tiny bright-luminescent patches, only faintly visible in this picture. The absence of luminescence in the brachiopods suggests that they have been preserved without major amounts of recrystallization. 
ronments, such penetration results from infestation by photosynthetic microbes living mostly in the upper photic zone at water depths extending to about $20 \mathrm{~m}$ (Budd \& Perkins 1980). The depth of the photic zone depends on several factors, such as angle of incidence and turbidity of the water column (Perry \& Macdonald 2002).

The linear arrays of fluid inclusions cannot have resulted from the healing of microfractures, nor can they have formed as fission tracks. Microfractures are planar and not linear like the arrays of fluid inclusions. Fission tracks are more or less randomly oriented, short, and straight. The structures observed in this study form long groups of inclusions that are preferentially oriented along grain margins, and aligned to form curvilinear and bifurcating arrays.

FLUIDS IN MicRoBoringS

\section{Cathodoluminescence petrography}

Calcite overgrowths sealed the microborings and preserved them as fluid inclusions. Brachiopod shells from this study are commonly overgrown by a thin $(30$ to $50 \mu \mathrm{m}$ ) rind of overgrowth calcite cement. Precipitation of some of the rinds predates fossiliferous sedimentation (Fig. 12). Thus, some of the rinds are undoubtedly marine in origin. Other overgrowth cements predate compaction and have a cement stratigraphy that indi- cates precipitation before and during Pennsylvanian cycle-bounding surfaces of subaerial exposure (Buijs \& Goldstein 2001). This timing indicates that cementation would have taken place early in the diagenetic history of the rock. One would expect that the fluid inclusions would originally have been filled with marine, modified marine, or meteoric water at a low temperature, or with gases generated by the decomposition of organic matter in the shallow subsurface.

\section{Fluid-inclusion petrography}

From observed phase-ratios and microthermometric analyses among fluid inclusions in linear arrays (fluidinclusion assemblages; Goldstein \& Reynolds 1994), the degree of re-equilibration and the mechanisms of shape change of tubular microborings were evaluated. Fluid inclusions in the samples contain either one phase (aqueous liquid), two phases (aqueous liquid and a bubble) with variable liquid-to-vapor ratio (L:V ratio), or three phases (oil, aqueous liquid, and gas). The presence of two-phase inclusions and oil in inclusions indicates reequilibration of fluid inclusions at high temperature through stretching or leakage and refilling (e.g., Goldstein 1986, Burruss 1987, Prezbindowski \& Larese 1987). Other oil inclusions in this core are known only from secondary fluid inclusions in late-stage fracturefilling calcite cement. Finding oil in microborings would indicate that the fluids in the microborings leaked and

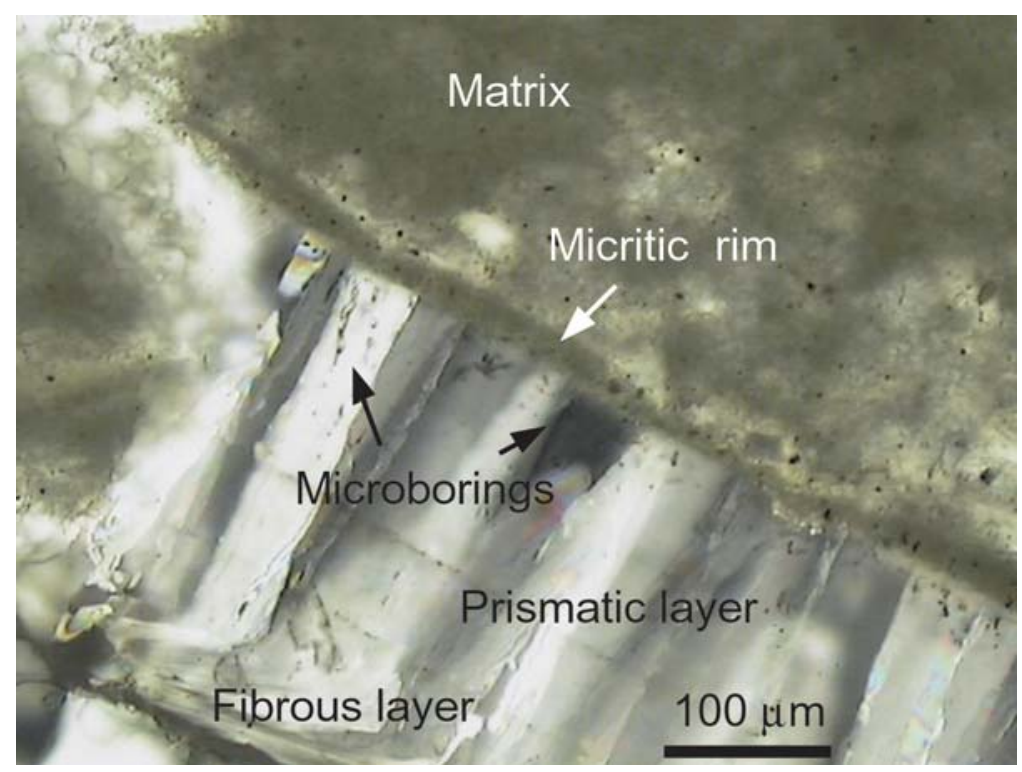

FIG. 11. Transmitted-light photomicrograph in crossed polars showing a brachiopod fragment with microborings and a micritic rim. Note the preservation of the prismatic layer in the fragment. 

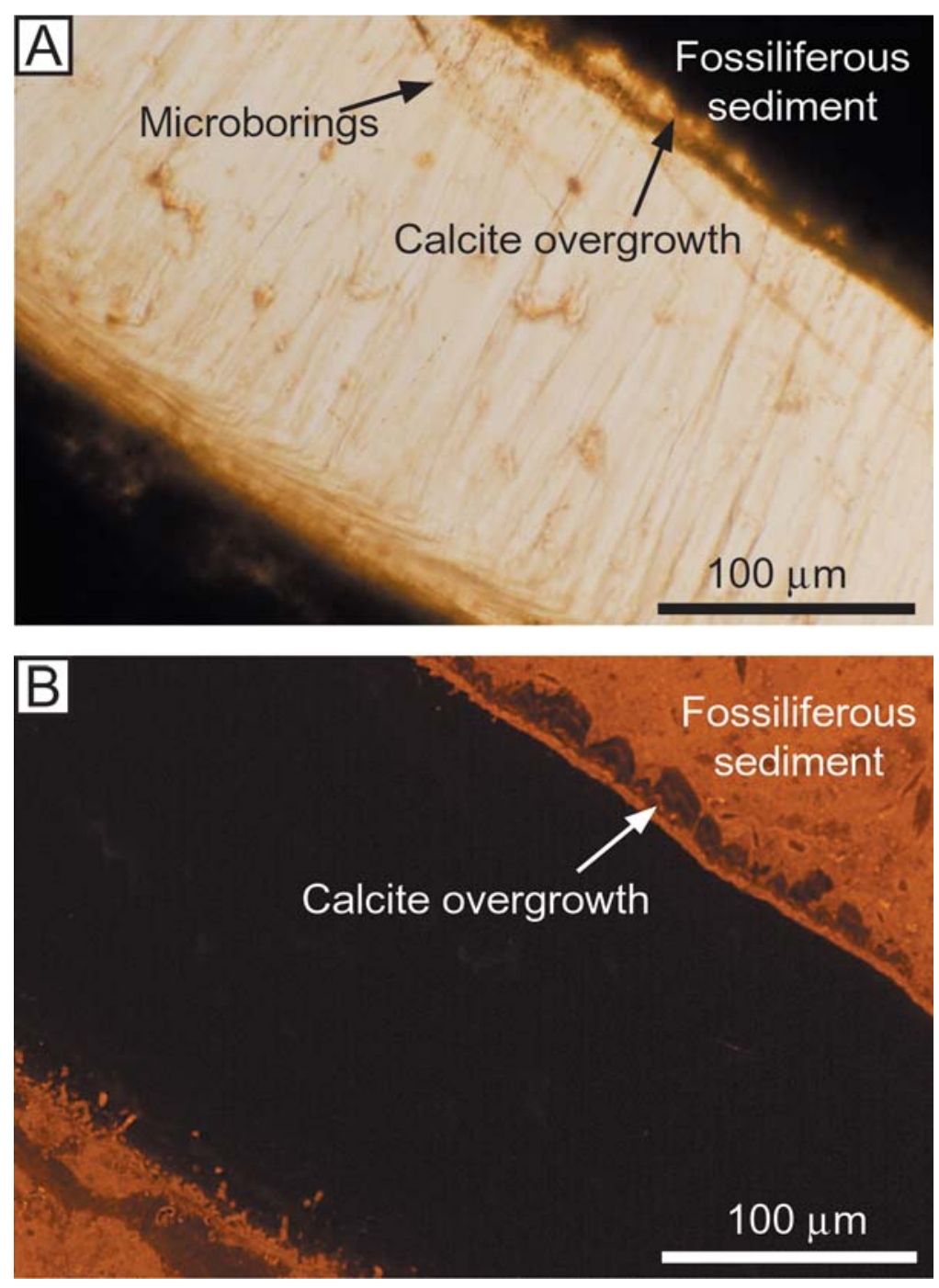

FIG. 12. (A) Transmitted-light, thick-section photomicrograph of brachiopod fragment showing calcite overgrowth predating deposition of overlying dense micritic sediment. (B) Photomicrograph of the same field of view with cathodoluminescence illumination. Notice growth-zoned calcite overgrowths that predate deposition of fossiliferous micritic sediments above.

refilled after significant burial. They originally would have contained a low-temperature marine or meteoric aqueous phase or biogenic gas.

The one-phase aqueous liquid inclusions appear alongside, and in linear trend, with two-phase inclusions that have a variable $\mathrm{L}: \mathrm{V}$ ratio. This juxtaposition suggests a necking down of two-phase inclusions (Fig. 13). Overall, the L:V ratio of inclusions in these fluid-inclusion assemblages is high, which is evidence against het- erogeneous entrapment of a separate gas and liquid phase.

Some inclusions appear to contain solid organic matter with a brownish yellow coloration together with the aqueous liquid. This organic matter does not appear to be associated with the more gas-rich linear arrays of inclusions or oil, which is evidence against in situ production of gas or oil within inclusions from the breakdown of organic matter. 
Some linear arrays appear to be dominated by gasrich fluid inclusions, containing only minor amounts of aqueous liquid. Some of these inclusions have undoubtedly leaked during preparation. Many of them, however, are small inclusions contained well within the mineral host, where they are judged to be unlikely to have leaked during preparation. The $\mathrm{L}: \mathrm{V}$ ratio in these fluid-inclusion assemblages is commonly greater than $50 \%$. Because solid organic matter in inclusions does not seem to be associated with in situ generation of gas, the presence of the large amount of gas in these inclusions likely represents heterogeneous entrapment of separate gas and liquid phases during initial entrapment or re-equilibration of the inclusions.

\section{Fluid-inclusion microthermometry}

Fluid-inclusion assemblages, containing aqueous fluid inclusions with the most consistent $\mathrm{L}: \mathrm{V}$ ratio, were heated to yield homogenization temperatures $\left(T_{h}\right)$. In addition to all-liquid inclusions (already homogenized at room temperature), two-phase inclusions produced highly variable temperatures of homogenization that range from as low as $72^{\circ} \mathrm{C}$ and scatter broadly up to $120^{\circ} \mathrm{C}$, where heating was discontinued. Inclusions with sizable bubbles remained at $140^{\circ} \mathrm{C}$, indicating that even higher temperatures would be needed to homogenize those inclusions. This is beyond the approximately $140^{\circ} \mathrm{C}$ upper limit of $\mathrm{T}_{\mathrm{h}}$ that has typically been observed in these rocks (Bergmann \& Luczaj 1995, Buijs \& Goldstein 2003).

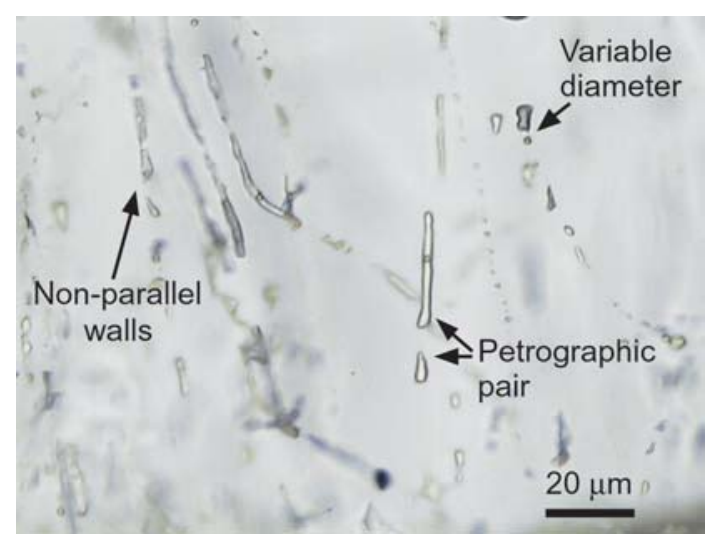

FIG. 13. Transmitted-light, thick-section photomicrograph of several arrays of fluid inclusions. The petrographic pair of inclusions marked consists of a smaller one-phase aqueous liquid inclusion and a larger two-phase aqueous liquid + vapor inclusion. Other arrays contain similar inclusions with variable $\mathrm{L}: \mathrm{V}$ ratios, variable diameter and non-parallel walls. The characteristics of these arrays were likely formed as a result of necking-down of the original microboring.
Together, the petrographic observations and $\mathrm{T}_{h}$ data indicate thermal re-equilibration of the inclusions. Cooling and necking-down of inclusions after the appearance of a bubble followed this step.

Data on the temperature of final melting of ice $\left(\mathrm{T}_{\mathrm{m} \text { ice }}\right)$ are also quite variable, with a majority of inclusions in the range of $-3.2^{\circ}$ to $-0.1^{\circ} \mathrm{C}$ (Fig. 14). Use of the seawater-salt-equivalent calibration of Goldstein \& Reynolds (1994) yields salinities ranging from 0.1 to 6.3 wt.\%, values consistent with fluids ranging from fresh to slightly evaporated seawater. Three outliers at $-10.0^{\circ},-13.4^{\circ}$ and $-25.0^{\circ} \mathrm{C}$ are similar to the salinity of higher-salinity fluids trapped at higher temperature in post-burial dolomite cements, as documented in other studies (Buijs \& Goldstein 2003; Fig. 14).

These data on $\mathrm{T}_{\mathrm{m}}$ ice suggest that many fluid inclusions still contain the modified marine water and freshwater originally entrapped in the inclusions. These inclusions apparently stretched to generate vapor bubbles during burial heating. Other inclusions contain the high-salinity pore fluid that was present during burial heating. Those inclusions must have leaked and refilled with the ambient pore fluid present during burial heating.

\section{Character of Change in Shape of Original Microborings}

We have demonstrated that the linear arrays of fluid inclusions were formed by tubular microborings that were overgrown by later micritic or calcite cement. The original shapes of similar microborings from presentday shells are more or less known as being continuous

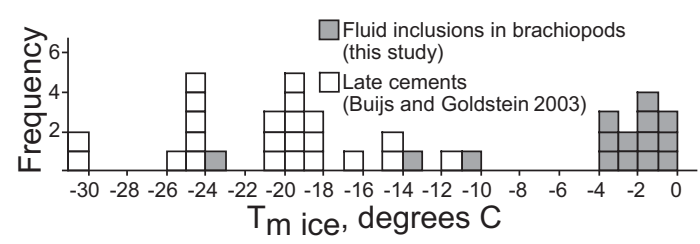

FIG. 14. Histogram of data on temperature of final melting of ice $\left(\mathrm{T}_{\mathrm{m} \text { ice }}\right)$ from tubular fluid inclusions in brachiopods (gray blocks) compared with $\mathrm{T}_{\mathrm{m}}$ ice data from fluid inclusions from late cements out of the same stratigraphic interval (white blocks). The $T_{m}$ ice data for inclusions from the brachiopods are quite variable, with a majority of inclusions in the range of $-3.2^{\circ}$ to $-0.1^{\circ} \mathrm{C}$. This information yields salinities ranging from 0.1 to $6.3 \mathrm{wt} . \%$ seawater salt equivalent, values consistent with fluids ranging from fresh to slightly evaporated seawater (Goldstein \& Reynolds 1994). Outliers at $-10.0^{\circ},-13.4^{\circ}$ and $-25.0^{\circ} \mathrm{C}$ are similar in composition to the higher-salinity fluids trapped at higher temperature in post-burial dolomite, documented from other studies (Buijs \& Goldstein 2003). 
tubules of relatively even diameter, lacking calcite partitions (Fig. 1; e.g., Golubic et al. 1975). The 300-million-year-old borings have clearly been altered from those original shapes through processes that resulted in the division of the borings into a series of separate fluid inclusions aligned along the original path of the boring. These changes can be used to evaluate the stability of ancient microborings in calcite. These findings have important implications for the preservation of microbial traces in the most ancient rocks and extraterrestrial materials, and provide a model for the morphology of microbial traces after they have been altered.

The character of modified microborings also can be used to evaluate the mechanism of change in shape. It is possible that the microborings change shape as a closedsystem process or as an open-system process.

On average, only $35 \%$ of the wall-to-distal-inclusion length of the arrays is preserved as fluid inclusions, with the remaining $64 \%$ of the original length of the microborings closed off with calcite. Variance is high, with length of a linear array preserved ranging from less than $5 \%$ and up to about $85 \%$. There seems to be little difference between the three morphological types of linear arrays of inclusions (Table 1, Fig. 15). Percent preservation of wall-to-distal-inclusion length is $36 \%$ for type $1,36 \%$ for type 2 , and $32 \%$ for type 3 .

On average, about $74 \%$ of the proximal-to-distalinclusion length of the arrays is preserved as fluid inclusions, with the rest of the original microborings closed off with calcite, the degree of filling ranging from 30 to $100 \%$. There seems to be little difference between the three morphological types of linear arrays of inclusions (Table 1, Fig. 15). Percent preservation of proximal-to-distal-inclusion length is $73 \%$ for type $1,71 \%$ for type 2 , and $81 \%$ for type 3 .

These observations indicate that through time, the borings have changed significantly. A result of this process would be the development of arrays of aligned fluid inclusions.

\section{Observations Relating to Mechanism of Change in Shape of Microborings}

We present two hypotheses for the formation of the calcite separations that break up the original boring into the linear arrays of fluid inclusions observed. One possibility is that of necking down, where calcite is redistributed in a closed system, dissolved from the walls of the boring and reprecipitated elsewhere. This process would produce many fluid inclusions with lower surface-free-energy shapes than the original boring (Roedder 1984). The alternative is an open-system hypothesis in which the borings are open to external pore fluids from which calcite cement is precipitated. Several open-system scenarios could lead to precipitation of a calcite partition: (1) the boring is open to fluids during precipitation of the initial overgrowth of calcite, (2) fluids can migrate into the boring along crystal boundaries, (3) fluids can migrate into the boring along microfractures, and (4) thermal decrepitation can be followed by migration of fluids into the boring.

If each microboring were a closed system that had necked down to form multiple inclusions, then: 1) the diameter of inclusions would be greater than that of the original boring to maintain no change in volume, 2) the walls of microborings, originally rough, would now be smooth, 3) different inclusions along a linear array would have different diameters, and 4) inclusions might not consistently maintain the parallel walls of the original tubular boring (Fig. 16). Some of the inclusions along linear arrays seem to fit these criteria (Fig. 13); inclusions have highly variable diameters and tend to lack parallel walls. Those inclusions with parallel walls in the same linear arrays are thinner in diameter than those that lack parallel walls. This finding suggests that the inclusions with parallel walls retain the original diameter of the boring, and that the other inclusions were widened beyond the original diameter of the microboring through closed-system necking down. Necking down is supported also by fluid-inclusion data showing petrographic pairing of gas-rich and all-liquid inclusions, and $\mathrm{T}_{\mathrm{m}}$ ice data showing that many of the inclusions are filled with low-salinity fluid consistent with that responsible for early diagenesis of the rocks.

If the calcite partitions in the microborings formed in an open system, where borings were partially cemented with calcite, then the diameter of the linear arrays of tubular inclusions would not be significantly larger than the diameter of the original microborings (Fig. 16). The diameters among tubular inclusions in these linear arrays would not vary significantly, and the walls would be maintained more or less parallel along their length, except where the tip of the inclusion is reached. Inclusions more likely would preserve rough walls, similar to those observed in the inclusions containing organic matter. Linear arrays of inclusions that fit these criteria are also found in the samples (Fig. 7), suggesting that the mechanism for formation of partitions in some microborings involves partial cementation in an open system, in contrast to closed-system necking down. The introduction of calcite from outside the boring is supported by the observation of small areas of cathodoluminescent calcite within the generally nonluminescent brachiopod shell. These bright areas mimic the borings in size and shape, which suggests that the borings were filled with cathodoluminescent calcite (Fig. 17). The luminescence compares favorably to that of calcite cement overgrowths on the brachiopod shells, indicating that partial cementation of the borings may have started early in the diagenetic history of the limestone. The fluid-inclusion microthermometry presented here also indicates thermal re-equilibration through leakage and refilling for some inclusions, suggesting that some tubular inclusions were open to outside pore fluids, through which the ions needed for calcite cement could have been introduced. 


\section{Discussion}

\section{Implications for fluid inclusions}

We have demonstrated that fluid inclusions can form where minerals are bored by endolithic microbes and are overgrown by cement. This new class of fluid inclu- sion forms from a vacuole that is biological in origin, and may form in any environment where microbes penetrate into detrital or fossil mineral grains.

Micro-organisms may initiate directed dissolution of mineral substrates owing to their ability to form chemical micro-environments at the mineral surface (Ehrlich 2002). Microbes perturb their geochemical environment

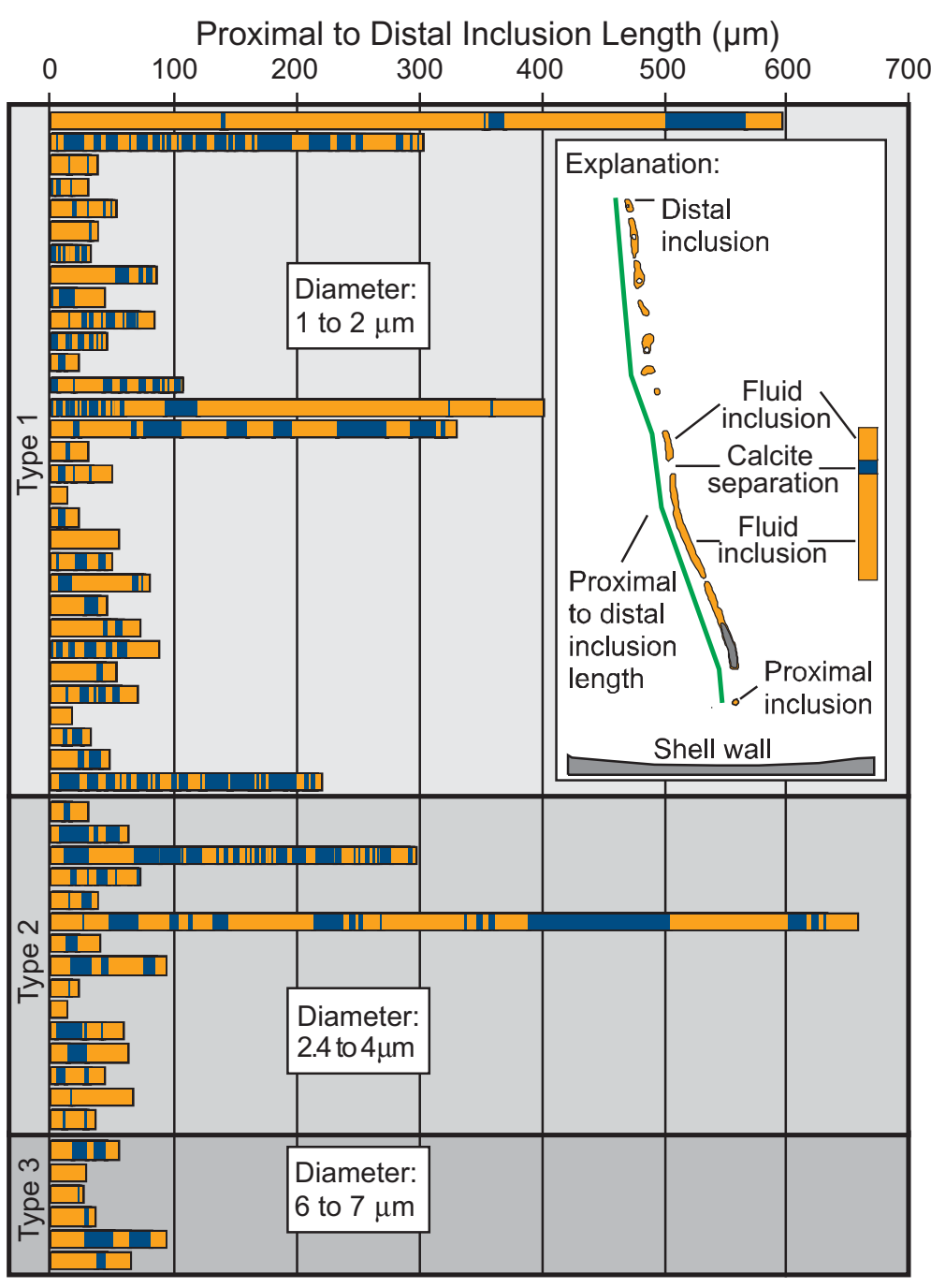

FIG. 15. Bar diagram of fifty-two measured linear arrays of inclusions. The length of each bar (in $\mu \mathrm{m}$ ) represents the length between the inclusion most proximal to the shell wall and the inclusion most distal (green line on the inset explanation). Blocks dividing the bars represent lengths of inclusions (orange) and lengths of calcite-filled areas separating the inclusions (blue). The plot is grouped according to type of array and sorted according to diameter, with the smallest diameter at the top. The inset explanation indicates schematically how the arrays were measured and shows how a part of an array of fluid inclusions is presented in orange and blue blocks. See Table 1 for the descriptive statistics of each type of array. 
by producing reactive chemicals or by direct interaction between cellular or exopolysaccharide material, shifting mineral equilibrium in the immediate vicinity of microbial attachment (Ehrlich 2002). Carbonates will dissolve in response to a decrease in $\mathrm{pH}$, commonly caused by the production of $\mathrm{CO}_{2}$ from microbial respiration (Chapelle 2001). Algae and cyanobacteria are typically oxygenic phototrophs, although many are capable of chemo-organotrophic or enzymatic metabolism of organic carbon and of the production of $\mathrm{CO}_{2}$ in darkness. Chemo-organotrophic organisms, such as fungi, also produce $\mathrm{CO}_{2}$ as a byproduct of metabolism (Madigan et al. 2002). These are possible mechanisms for carbonate dissolution and microbial boring in the samples studied.

Whereas metabolic byproducts may drive dissolution of the carbonate substrate, the distinct morphology of the borings suggests more direct control during their formation. Green and red algae, cyanobacteria, and fungi all exhibit the branched morphologies represented by the borings (Golubic et al. 1975) and, therefore, their borings may be initiated directly through interaction between the cell wall of the endolithic organism and the carbonate surface. Recent studies by Davis et al. (2002) and Patch et al. (2002) suggest that some micro-organisms attach and bore into the carbonate surface, forming distinct cell-shaped pits, rather than widespread indistinct etching. The endolithic borings examined in this study are consistent with a directed interaction of cell-wall reactive groups with the carbonate substrate.

We have demonstrated that the shapes of the microendolithic borings have been changed and now are preserved as linear arrays of fluid inclusions. These linear arrays of inclusions are distinctly different from inclusions formed by annealing of fractures in that they are tubular and arranged linearly as opposed to being arranged on two-dimensional surfaces. A comparison between the presumed original form of the microborings and their present morphology is useful in demonstrating the rate, abundance, and mechanism of fluid-inclusion alteration in calcite.

In these 300-million-year-old samples, all of the microborings have become modified in their shapes. The extent of alteration, however, is highly variable even within a single grain. This fact illustrates the nearubiquitous nature of change in shape of aqueous inclusions in calcite of similar age and history, and the complexity of the process of modification. The process is superficially similar to necking down of an elongate inclusion into many smaller inclusions, but the mechanism of alteration seems to involve both the closed-system process of necking down and the open-system process of introduction of new calcite cement into the original vacuole. Further, the microthermometric data show that these kinds of inclusions are prone both to stretching, and to leakage and refilling. As such, they are not likely to produce highly reliable data reflecting the conditions of initial entrapment of the fluid in the inclusions.

\section{Paleoecological implications}

Despite the variable modifications of the original microborings, some are surprisingly well preserved, exhibiting much of their assumed original morphology. Some of the inclusions may even contain solid organic matter from the original micro-organism. With such preservation, morphological comparison with modern analogs is possible, and allows for more detailed paleoecological interpretations. Investigators of modern microborings, for example, find assemblages that are specific to certain photic or tidal regimes. Similar studies could be performed on ancient examples to aid in paleoenvironmental reconstructions (Budd \& Perkins 1980, Bromley 1994, Vogel et al. 2000, Edinger 2001).

Regarding these microborings as fluid inclusions provides new tools for paleoecological reconstruction that may eliminate much of the ambiguity that has been prevalent in evaluating the timing of formation of microbial trace fossils. For example, one can ask if an endolithic boring found in an Archean rock is Archean in age, or whether it represents a modern overprint on the outcrop in which endolithic microbes are currently living? A similar problem exists for meteorites that have been sitting on the surface of the Earth for an extended period of time, where Earth-bound endolithic borings might be misinterpreted as evidence of extraterrestrial life.

The petrographic techniques commonly applied in fluid-inclusion work can be used to evaluate the timing of formation of the microbial traces by applying petrographic, superpositional, and cross-cutting relationships (Hasiotis et al. 2002). For example, to demonstrate that microendolithic trace fossils are ancient (Fig. 18), one could show that the traces are related to the growth history of the mineral phase present. Microborings could be clustered along former growth-surfaces and be oriented relative to those surfaces, and in turn, overgrown by subsequent zones of mineral growth. Similarly, the microborings could be formed in other mineral surfaces (such as detrital grains), oriented relative to those surfaces, and overgrown by later mineral growth. Finally, microborings could form along fracture surfaces that were later overgrown by subsequent precipitation of mineral phases. If the microborings were produced after the minerals were formed, they would cut across the latest phase of mineral growth. A similar petrographic approach should be applied in evaluating the timing of formation of microbial traces in all ancient terrestrial and extraterrestrial materials.

Microbial borings are significant in understanding the paleoecological history of the rocks in which they are preserved. Microendolithic borings can be considered as trace fossils that preserve evidence of microbial 

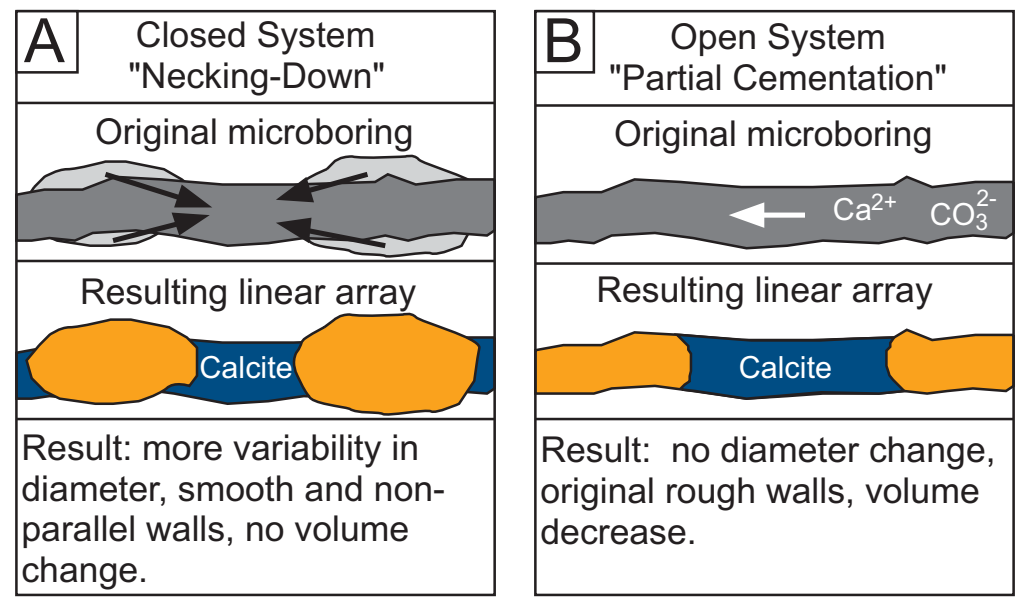

Fig. 16. Cartoon of two proposed mechanisms for the formation of the calcite separations that break up the original boring into linear arrays of fluid inclusions. (A) The first hypothesized mechanism, "necking down", occurs in a closed system in which calcite is redistributed within the original microboring. This redistribution results in an array of inclusions of variable diameter with smooth and non-parallel walls. Theoretically, the volume of the microboring should remain constant. (B) The second hypothesized mechanism, "partial cementation", takes place in an open system in which $\mathrm{Ca}^{2+}$ and $\mathrm{CO}_{3}{ }^{2-}$ are introduced from outside of the shell and then precipitated as calcite in the microboring. The resulting array contains inclusions of more constant diameter with relatively rough and parallel walls. The volume of the original microboring has decreased owing to shortening of length.

interactions with a mineral surface (Golubic et al. 1975 , Hasiotis et al. 2002, Taylor \& Wilson 2002). Microbes are an important part of any ancient ecosystem, yet their abundance and role are seldom preserved. In the Pennsylvanian-Permian example presented here, their state of preservation provides clues about the depositional environment and ecosystem not otherwise recorded by macrofossils. Such traces provide information that can be used to evaluate the importance of bioerosion, sedimentation rate, water depth, light penetration and other aspects of paleoenvironments (e.g., Golubic et al. 1975, Warme 1975, Perry \& Macdonald 2002, Taylor \& Wilson 2002). If it were not for the preservation of microendolithic trace fossils, detailed information of their behavior and role in ancient ecosystems would be lost or inferred from microfossils preserved elsewhere in the geological record.

\section{Implications in the search for extraterrestrial life}

Microendolithic borings can also be important trace fossils preserved in extraterrestrial rocks found on the surface of the Earth and those collected from other planetary bodies (Hasiotis et al. 2002). Since the discovery and controversial interpretation of bacteria-shaped bodies and magnetite within the ALH84001 meteorite (McKay et al. 1996), researchers have been question- ing how evidence for microbes could be preserved in rocks. We suggest that microendolithic borings, and the linear arrays of fluid inclusions to which they are altered, could also be preserved in extraterrestrial materials. An endolithic life-style may be preferred in such extraterrestrial environments where large fluctuations in temperature, high radiation, and limited amounts of water impose high stresses on life forms (Clark 1998, Klein 1998, Horneck 2000, Rothschild \& Mancinelli 2001). By being sheltered in hard substrates, these microbes could perhaps be shielded from the extreme conditions. We believe that materials from Mars are likely to be rich in carbonate minerals (McKay \& Nedell 1988, Kempe \& Kazmierczak 1997, Parnell et al. 2002). Because microborings form easily in carbonate minerals on Earth, one might postulate that Martian carbonates would be fertile ground for the preservation of extraterrestrial microbial traces. If carbonate minerals were overgrown by cements in those materials, then the microborings might be preserved as fluid inclusions. The inclusions themselves might even contain the organic remains of the ancient life forms that formed the trace fossils. It is likely that if any Martian microborings exist, they could be preserved as linear, curvilinear, or branched arrays of fluid inclusions. As the age of potential microbial traces in Martian material would likely be quite ancient [Early Hesperian? i.e., older than 3.6 
billion years; Tanaka (1986), Head et al. (2001)], the processes of modification of the original microborings will have taken place more extensively, compared to our 300-million-year-old rocks. This certainly depends on the fluid and thermal history experienced by any Martian material. Given the likely age of such materials, we expect that microbial traces could be preserved in Martian carbonate samples, but likely as linear arrays of fluid inclusions.
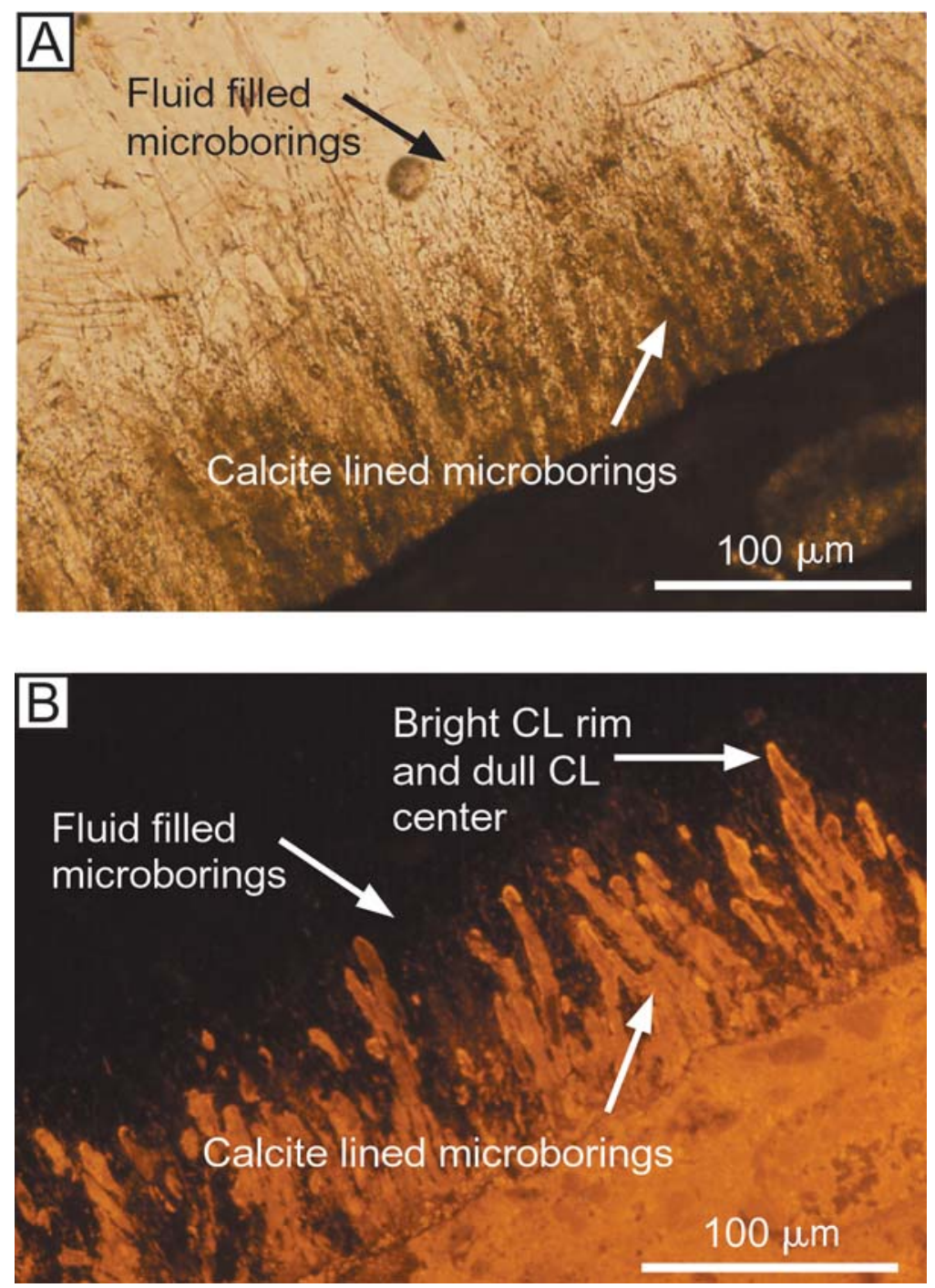

FIG. 17. Photomicrographs illustrating filling of microborings with micrite and calcite cement. (A) Transmitted-light, thick-section photomicrograph of microborings in margin of brachiopod fragment. Dark area along base of brachiopod is micritic matrix. Borings near shell margin are lined with micrite and filled with calcite cement. Borings in shell interior are filled with fluid and preserved as fluid inclusions. (B) Photomicrograph of the same field of view as (A), but with cathodoluminescence illumination. Proximal microborings have a bright rim and a dull interior, indicating cementation with micrite and coarser calcite cement. 


\section{Conclusions}

Microborings in calcite grains can be overgrown by calcite cement to trap fluid inclusions of biological origin. The microborings are formed by a variety of micro-organisms, producing various morphologies. This new class of fluid inclusion tends to be modified through thermal re-equilibration, including leaking and refilling, and stretching. The tubular microborings are unstable compared to many other fluid inclusions, and they tend toward segmentation, with calcite partitions that break the original boring into an array of aligned fluid inclusions. Mechanisms of formation of partitions include closed-system necking down and open-system precipitation of calcite cement. Despite the processes of alteration of the borings, their original morphology still can be determined in ancient terrestrial (and extraterrestrial?) materials as linear arrays of fluid inclusions that cut across crystal-growth directions. Standard petrographic methods, commonly applied to determining the timing of entrapment of fluid inclusions, can be applied

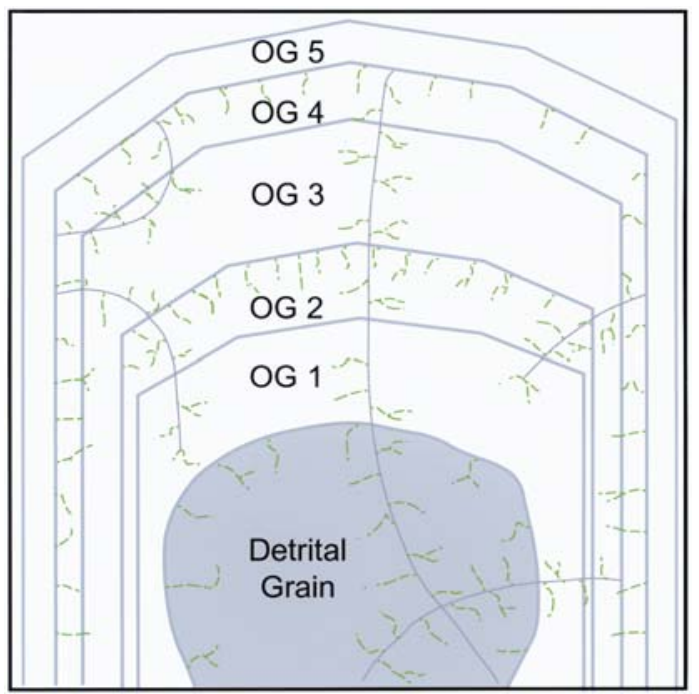

FIG. 18. Sketch illustrating the use of fluid-inclusion petrography to evaluate the timing of formation of microborings. Borings that formed on the surface of detrital grains and shell fragments may be overgrown by later cements, demonstrating that the microborings, were formed before precipitation of overgrowth 1 (OG 1). After further crystalgrowth to precipitate the next growth-zone (OG 2), microborings could have penetrated the crystal surface. Further precipitation (OG 3 ) on the surface would constrain the age of the second generation of microborings. After further precipitation (OG 4), the crystal could have been fractured. Microborings could have penetrated from the crystal faces and fracture surfaces. Further precipitation (OG 5) would constrain the timing of those borings. to microbial trace fossils to distinguish between ancient material and a modern overprint. Inclusions such as these potentially could expand our knowledge of how life formed and evolved here on Earth and possibly elsewhere in our Solar System.

\section{ACKNOWLEDGEMENTS}

We thank Alan J. Anderson for his efforts as Associate Editor. Robert Martin, Evan Edinger and an anonymous referee provided helpful suggestions to improve this manuscript. Paul Enos generously gave us access to samples of modern materials from South Florida. This research was funded by a grant from the American Chemical Society Petroleum Research Fund, ACSPRF\#35882-AC8.

\section{REFERENCES}

AtLAS, R.M. \& BARTHA, R. (1998): Microbial Ecology: Fundamentals and Applications ( $4^{\text {th }}$ ed.). Benjamin/Cummings, Menlo Park, California.

Bergmann, B.J. \& LucZaJ, J.A. (1995): Preliminary fluid inclusion evidence for the mechanism of dolomitization in the Lower Permian Chase Group, Hugoton Embayment, southwest Kansas. Am. Assoc. Petroleum Geol., Bull. 79, 1400 (abstr.)..

BromLey, R.G. (1994): The palaeoecology of bioerosion. In The Palaeobiology of Trace Fossils (S.K. Donovan, ed.). John Wiley, New York, N.Y. (134-154).

BudD, D.A. \& PERKINS, R.D. (1980): Bathymetric zonation and paleoecological significance of microborings in Puerto Rican shelf and slope sediments. J. Sed. Petrol. 50, 881904.

BuiJs, G.J.A. \& GolDSTEIN, R.H. (2001): Importance of climate and sequence architecture on meteoric diagenesis of Pennsylvanian limestone reservoirs, western Kansas. Am. Assoc. Petroleum Geol., Annual Meeting, Ext. Abstr., 29.

\&

(2003): Salinity driven fluid flow controls thermal and diagenetic history, PennsylvanianPermian, western Kansas. Am. Assoc. Petroleum Geol., Annual Meeting, Ext. Abstr., 21.

Burruss, R.C. (1987): Paleotemperatures from fluid inclusions: advances in theory and technique. In Thermal History of Sedimentary Basins, Methods and Case Histories (N.D. Naeser \& T.H. McCulloh, eds.). Am. Assoc. Petroleum Geol., Spec. Publ. 41, 121-131.

Chapelle, F.H. (2001): Ground-Water Microbiology and Geochemistry ( $2^{\text {nd }}$ ed.). John Wiley \& Sons, New York, N.Y.

Clark, B.C. (1998): Surviving the limits to life at the surface of Mars. J. Geophys. Res. 103, 28545-28555. 
Davis, K.J., Patch, F.E., Conrad, P.G. \& LutTGe, A. (2002): Microbial recognition of magnesite and dolomite surfaces: implications for carbonate dissolution rates. Geol. Soc. Am., Abstr. Programs 34(6), 19.

EdINGER, E.N. (2001): Bioerosion. In Palaeobiology 2 (D.E.G. Briggs \& P.R. Crowther, eds.). , Blackwell Science, Oxford, U.K. (273-277).

EHRLICH, H.L. (2002): Geomicrobiology (4 ${ }^{\text {th }}$ ed.). Dekker, New York, N.Y.

GoLDSTEIN, R.H. (1986): Reequilibration of fluid inclusions in low-temperature calcium-carbonate cement. Geology 14, 792-795.

Anderson, J.E. \& Bowman, M.W. (1991): Diagenetic responses to sea-level change: integration of field, stable-isotope, paleosol, paleokarst, fluid-inclusion, and cement-stratigraphy research to determine history and magnitude of sea-level fluctuation. In Sedimentary Modeling: Computer Simulations and Methods for Improved Parameter Definition. Kansas Geol. Surv., Publ. Bull. 233, 139-162.

\& REYNOLDS, T.J. (1994): Systematics of fluid inclusions in diagenetic minerals. Soc. Econ. Paleontol. Mineral., Short Course $\mathbf{3 1 .}$

Golubic, S., Perkins, R.D. \& Lukas, K.J. (1975): Boring microorganisms and microborings in carbonate substrates. In The Study of Trace Fossils (R.W. Frey, ed.). SpringerVerlag, New York, N.Y. (229-259).

\& SEONG-JOO, LEE (1999): Early cyanobacterial fossil record: preservation, paleoenvironments and identification. Eur. J. Phycol. 34, 339-348.

Hasiotis, S.T., Rogers, J.R. \& Goldstein, R.H. (2002): Traces of life: macro- and microscopic evidence of past and present biogenic activity potentially preserved in extraterrestrial sediments and rocks. XXXIII Lunar and Planetary Science Conf., Abstr. 2054.pdf (CD-ROM).

Head, J.W., Greeley, R., Golombek, M.P., Hartmann, W.K., Hauber, E., Jaumann, R., Masson, P., Neukum, G., NYQUIST, L.E. \& CARR, M.H. (2001): Geological processes and evolution. Space Science Rev. 96(1), 263-292.

Horneck, G. (2000): The microbial world and the case for Mars. Planet. Space Sci. 48, 1053-1063.

Kempe, S. \& KazmiercZaK, J. (1997): A terrestrial model for an alkaline martian hydrosphere. Planet. Space Sci. 45, 1493-1495.

KLEIN, H.P. (1998): The search for life on Mars: what we learned from Viking. J. Geophys. Res. 103, 28463-28466.

LuczaJ, J.A. \& Goldstein, R.H. (2000): Diagenesis of the lower Permian Krider Member, southwest Kansas: fluid inclusion, $\mathrm{U}-\mathrm{Pb}$, and fission-track evidence for reflux dolomitization during latest Permian time. J. Sed. Res. 70 , 762-773.

Madigan, M.T., Parker, J. \& Martinko, J.M. (2002): Brock Biology of Microorganisms $\left(10^{\text {th }}\right.$ ed.). Prentice Hall, Englewood Cliffs, N.J.

McKay, C.P. \& NedELl, S.S. (1988): Are there carbonate deposits in the Valles Marineris, Mars? Icarus 73, 142-148.

McKay, D.S., Gibson, E.K., JR., Thomas-KePETA, K.L., VALi, H., RomaneK, C.S., Clemett, S.J., Chillier, X.D.F., MaEchling, C.R. \& ZARE, R.N. (1996): Search for past life on Mars: possible relic biologic activity in Martian meteorite ALH84001. Science 273, 924-930.

Parnell, J., Mazzini, A. \& Honghan, C. (2002): Fluid inclusion studies of chemosynthetic carbonates: strategy for seeking life on Mars. Astrobiology 2, 43-57.

Patch, F.E., Davis, K.J., Conrad, P.G. \& LutTGe, A. (2002): Calcite surface recognition by Shewanella Oneidensis MR1: insight into carbonate dissolution rates in biological environments. Geol. Soc. Am., Abstr. Programs 34(6), 19.

PERRY, C.T. \& MACDONALD, I.A. (2002): Impacts of light penetration on the bathymetry of reef microboring communities: implications for the development of microendolithic trace assemblages. Palaeogeography, Palaeoclimatology, Palaeoecology 186, 101-113.

PREZBindowski, D.R. \& LARESE, R.E. (1987): Experimental stretching of fluid inclusions in calcite - implications for diagenetic studies. Geology 15, 333-336.

RoEdDER, E. (1984): Fluid inclusions. Rev. Mineral. 12

RoThSCHILD, L.J. \& MANCINELLI, R.L. (2001): Life in extreme environments. Nature 409, 1092-1101.

TANAKA, K.L. (1986): The stratigraphy of Mars. J. Geophys. Res. 91, E139-E158.

TAYLOR, P.D. \& Wilson, M.A. (2002): A new terminology for marine organisms inhabiting hard substrates. Palaios 17, $522-525$.

Vogel, K., GeKtidis, M., Golubic, S., Kiene, W.E. \& RadtKe, G. (2000): Experimental studies on microbial bioerosion at Lee Stocking Island, Bahamas and One Tree Island, Great Barrier Reef, Australia: implications for paleoecological reconstructions. Lethaia 33, 190-204.

WARME, J. (1975): Borings as trace fossils, and the processes of marine bioerosion. In The Study of Trace Fossils (R.W. Frey, ed.). Springer-Verlag, New York, N.Y. (181-227).

Received November 28, 2002, revised manuscript accepted August 25, 2003. 